\title{
Investigation on chemical effects on GMZ bentonite used as buffer materials
}

\author{
Wei-Min Ye \\ ${ }^{1}$ Department of Geotechnical Engineering, College of civil engineering, Tongji University, Shanghai 200092, China \\ ${ }^{2}$ Key Laboratory of Geotechnical and Underground Engineering of Ministry of Education, Tongji University, Shanghai 200092, China
}

\begin{abstract}
GMZ bentonite has been selected as a buffer/backfill material for the design of Chinese HLW repository due to its suitable properties. Investigations have been conducted on this material to have a better understanding of its engineering behavior. In this paper, a review of the studies on the chemical effects in GMZ bentonite is presented. The adsorption of radionuclides $\mathrm{Ni}(\mathrm{II}), \mathrm{Cr}(\mathrm{III})$ and $\mathrm{Eu}(\mathrm{III})$ etc. on $\mathrm{GMZ}$ bentonite is investigated and the influences of external chemical agents are assessed. Some modifications on GMZ bentonite have been implemented to improve its adsorption properties. In the meantime, the influences of $\mathrm{NaOH}$ solutions with variations in concentration and $\mathrm{pH}$ values on hydraulic conductivity, mechanical behavior and mineralogy of GMZ bentonite are investigated with consideration of temperature. Effects of salt solutions are also assessed in different studies using solutions of $\mathrm{Na}^{+}$and $\mathrm{Ca}^{2+}$, which are the predominant cations in the groundwater of Beishan area. It is observed that both cations influence the buffering behavior of bentonite at a different degree. Further investigations should be done for better understanding the influences of coupling factors and time on the chemical behavior of material.
\end{abstract}

\section{Introduction}

Deep geological storage is a widely accepted technology for disposal of high-level radioactive wastes. Bentonite or bentonite-based materials has been found to be an appropriate material for surrounding the habitual canisters in hard rocks where the waste is placed ([1-2]) due to its particular micro-porous structure, low hydraulic conductivity, high swelling and self-sealing capacity and good sorption properties ([3-8]).

Until now, different kinds of bentonite have been selected as the best candidate to act as a buffer/backfill material in HLW repositories. FEBEX bentonite, obtained from deposits located in Almería, has been selected for such purpose by the Spanish Agency for Radioactive Waste Management (ENRESA) ([9]). MX80 bentonite, extracted from Wyoming, has also been chosen as a buffer material in many disposal concepts in countries such as Finland ([10]), France ([11]), Sweden ([12]) and Germany ([13]). The Kunigel V1 and FoCa bentonites have been selected by Japan and France as candidates for HLW disposal ([14-15]).

During the long-term operation of the repository, the engineered barrier is characterized by coupled thermalhydraulic-mechanical (THM) behavior involving interactive processes such as the decay heat of vitrified waste, the infiltration of groundwater and the stress generation due to the ground pressure, the thermal loading and swelling pressure of the buffer material will take place ([16]). In order to understand the behavior of the canister/barrier/host rock system, the coupled THM processes within the compacted bentonite need to be modelled ([16-19]). For this reason, a number of theoretical proposals concerning THM analysis have been reported ([20-25]).

Meanwhile, chemical reactions inducing changes of buffer/backfill property of the artificial barrier could happen. Moreover, the degradation of the concrete in the repository could induce a notable rise of the groundwater $\mathrm{pH}$, which means an exposure of the bentonite to alkaline solutions ([26]). Then, bentonite properties such as radionuclides adsorption, hydraulic conductivity and swelling behavior may be affected by these external factors, results in an incorrect performance of the material for our expected engineering purposes in the isolation of HLW from the environment.

A great number of experimental studies dealing with the chemical effects on behavior of clayey soils are available in literature ([27-31]). Common view can be reached that effects of salt solutions on the expansion of clays have been always attributed to the effects of the diffuse double layer (DDL) ([31-32]). The behavior of clay particles is strongly influenced by the net interparticle repulsive minus attractive stress ( $\mathrm{R}$ - A) ([3335]). The thickness of the DDL and the net repulsive stress decreases as the concentration of the solution in the pores increases, which leads to true effective stress increases, resulting in contraction of the aggregates and shrinkage of the sample ([33]).

aye_tju@tongji.edu.cn 
The Chinese program of radioactive waste disposal in a deep geological media was launched in middle 1980s. According to the Chinese long-term plan for the implementation of such repositories, it will be put into operation by the middle of the 21 st Century ([36]). Currently, a preliminary concept of a multi-barrier HLW repository, which consists of a shaft-tunnel structure and located in saturated zone in granites ([37]), is adopted.

Gao-Miao-Zi (GMZ) bentonite has been selected for the construction of the engineered barrier $([4,38])$. Investigations have been conducted on GMZ bentonite to understand and characterize its engineering behaviors ([45,36,38-39]). In the meantime, Beishan in Gansu province has been chosen as the preferred construction site for Chinese repository ([4]). Previous in-situ investigation results show that the average total dissolved solids (TDS) of the groundwater in Beishan is $3-12 \mathrm{~g} / \mathrm{L}$, up to $80 \mathrm{~g} / \mathrm{L}$ ([40]). Obviously, investigation on behaviour of GMZ bentonite with consideration of the influence of pore fluid concentration is of great importance for Chinese HLW disposal program.

Investigations on mineralogy and chemical composition, mechanical properties, hydraulic behavior, swelling behavior, thermal conductivity, microstructure and volume change behavior were performed on GMZ bentonite ([4-5,36,38-39,41-45]. among others). ChinaMock-Up ([46]) was performed to assess the behavior of GMZ bentonite under coupled THM conditions

In this paper, an exhaustive review of the accumulated knowledge from literature about the chemical effects on the behavior of a GMZ bentonite-based buffer/backfill material in a HLW disposal is presented. Achievements in certain chemical-related factors affecting the properties of GMZ bentonite, such as adsorption capacity, hydraulic conductivity, and mechanical behavior, among others are presented. Problems that should be investigated are suggested for GMZ bentonite in the future.

\section{$2 \mathrm{GMZ}$ bentonite}

GMZ bentonite is a montmorillonite-dominant clay originated in the later Jurassic period ([41]). It is extracted from a vast deposit in the Inner Mongolia Chinese autonomous region, about $300 \mathrm{~km}$ northwest from Beijing. The deposit covers an area of about $72 \mathrm{~km}^{2}$, with 120 million tons of Na-bentonite from a total of 160 million tons of clay materials (Fig. 1) ([5]). The characteristic bedded ores have a waxy appearance and a soapy texture. Its formation was caused by the mineralization due to an interaction with ground water and weathering of the firstly formed continental volcanic sediments ([41]).

Investigations showed that GMZ bentonite is composed of $75.4 \%$ montmorillonite $11.7 \%$ quartz, $7.3 \%$ cristobalite, $4.3 \%$ feldspar, $0.5 \%$ calcite and $0.8 \%$ kaolinite ([42]). X-ray fluorescence spectrometry results show that the composition of GMZ bentonite is $\mathrm{SiO}_{2}$ $67.43 \%, \mathrm{Al}_{2} \mathrm{O}_{3} 14.20 \%, \mathrm{TFe}_{2} \mathrm{O}_{3} \quad 2.40 \%, \mathrm{Na}_{2} \mathrm{O} \quad 1.75 \%$, $\mathrm{CaO} 1.13 \%, \mathrm{~K}_{2} \mathrm{O} 0.73 \%, \mathrm{FeO} 0.29 \%, \mathrm{TiO}_{2} 0.12 \%, \mathrm{MgO}$ $0.10 \%, \mathrm{MnO} 0.02 \%$ and $\mathrm{P}_{2} \mathrm{O}_{5} 0.02 \%$ ([4,42]).

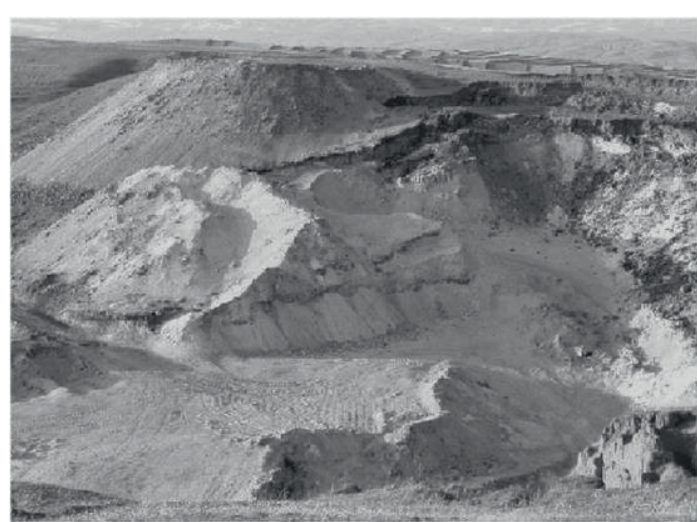

Figure 1. Open pit of GMZ bentonite deposit ([5]).

Table 1. Mineralogical composition of GMZ bentonite compared to the other three, in \% $([9,42,47-49])$.

\begin{tabular}{|c|c|c|c|c|}
\hline Bentonite & GMZ & MX-80 & FEBEX & $\begin{array}{c}\text { Kunigel- } \\
\text { V1 }\end{array}$ \\
\hline Montmorillonite & 75.4 & $65-82$ & $92 \pm 3$ & 47 \\
\hline Quarz & 11.7 & $4-12$ & $2 \pm 1$ & 0.6 \\
\hline Cristobalite & 7.3 & - & - & - \\
\hline Feldspar & 4.3 & $5-8$ & - & - \\
\hline Plagioclase & - & $8.2 \pm 2.7$ & $2 \pm 1$ & 4 \\
\hline Kaolinite & 0.8 & - & - & - \\
\hline Chalcedony & - & - & - & 37 \\
\hline
\end{tabular}

The high content of montmorillonite results in a high cation exchange capacity $(\mathrm{CEC}=77.30 \mathrm{meq} / 100 \mathrm{~g})$, a large plasticity index $(\mathrm{Ip}=275)$, and large specific surface area $\left(\mathrm{S}=570 \mathrm{~m}^{2} / \mathrm{g}\right)$. The major exchangeable cations are $\mathrm{Na}^{+}(43.36 \mathrm{meq} / 100 \mathrm{~g}), \mathrm{Ca}^{2+}(29.14 \mathrm{meq} / 100 \mathrm{~g}), \mathrm{Mg}^{2+}$ $(12.33 \mathrm{meq} / 100 \mathrm{~g})$ and $\mathrm{K}^{+}(2.51 \mathrm{meq} / 100 \mathrm{~g})$ ([42]). The mineral composition and some physical properties for the most used bentonites can be found in Table 1 and Table 2 , respectively.

Table 2. Some physical properties of GMZ bentonite compared to the other three $([9,42,47-49])$.

\begin{tabular}{llllll}
\hline Sample & $G_{s}$ & $w_{L}(\%)$ & $w_{P}$ & $I_{p}$ & $S\left(\mathrm{~m}^{2} / \mathrm{g}\right)$
\end{tabular}

$(\%)$

\begin{tabular}{llllll}
\hline GMZ & 2.66 & 313 & 38 & 275 & 570 \\
Mx-80 & 2.76 & 520 & 42 & 478 & 562 \\
FEBEX & 2.7 & $102 \pm 4$ & $53 \pm 3$ & $42 \pm 7$ & 725 \\
Kunigel- & 2.79 & 415 & 32 & 383 & 687
\end{tabular}

V1

With these characteristics and especially for the GMZ bentonite in the Chinese case, bentonites are ideal to be used as the buffer/backfill materials, which have suitable 
thermal, hydraulic, mechanical and physico-chemical properties.

\section{Chemical effects on the adsorption of radionuclides}

As backfill materials for engineered barrier, bentonite should has good adsorption capacity for preventing the escaping of the radionuclides, which possibly leaked from the canister, to the environment. Up to now, many contributions have made to investigate the chemical effects on the capacity of GMZ bentonite for the adsorption radionuclides ([50-61]).

The sorption of an important radionuclide such as $\mathrm{Ni}(\mathrm{II})$ on GMZ bentonite was studied under the effects of $\mathrm{pH}$, ionic strength, foreign ions, humic acid and temperature ([58]). The results indicated that the sorption process of $\mathrm{Ni}(\mathrm{II})$ quickly achieved the equilibration. Its kinetics can be described reasonably well by the following pseudosecond-order model ([62]):

$$
\frac{t}{q_{t}}=\frac{1}{2 k q_{\theta}^{2}}+\frac{1}{q_{\theta}} t
$$

Where, $\mathrm{k}\left(\mathrm{g} \mathrm{mg}^{-1} \mathrm{~h}^{-1}\right)$ is the pseudo-second-order rate constant of sorption, qt (mg g $\mathrm{g}^{-1}$ of dry mass) is the amount of $\mathrm{Ni}$ (II) sorbed on the surface of the adsorbent at time $\mathrm{t}(\mathrm{h})$, and qe ( $\mathrm{mg} \mathrm{g}-1$ of dry mass) is the equilibrium sorption capacity.

The sorption of $\mathrm{Ni}$ (II) was found to be strongly dependent on $\mathrm{pH}$. It increased with an increase in $\mathrm{pH}$ values lower than 8.5 , and then maintained a high level at values above 8.5. At a low $\mathrm{pH}$, the sorption was affected by the foreign cations, but not for high $\mathrm{pH}$. The same behavior was observed in the case of ionic strength. However, the presence of different foreign anions had no obvious influence on the sorption. The sorption process was dominated in a different way depending on the $\mathrm{pH}$. For low values, it was mainly dominated by outer-sphere complexation and exchange with $\mathrm{Na}^{+} / \mathrm{H}^{+}$; for high values, it was controlled by inner-sphere surface complexation. Humic acid (HA) also affected the process, increasing it at low $\mathrm{pH}$ and decreasing it at high $\mathrm{pH}$.

Lagmuir, Freundlich and DR models were used to simulate the temperature-dependent sorption isotherms of $\mathrm{Ni}$ (II) and thermodynamic parameters were calculated. The results showed that the sorption of Ni(II) on GMZ bentonite was endothermic and spontaneous.

Other studies were also performed on the capacity of GMZ bentonite for the adsorption of $\mathrm{Cr}(\mathrm{III})$, which can also be found in HLW. Influences of ionic strength, $\mathrm{pH}$, temperature and adsorbent dose variations on the process were studied ([54]).

The results showed that the adsorption capacity of bentonite increased with increasing $\mathrm{pH}$ from 2 to 7 . There was no significant change for higher $\mathrm{pH}$ values. $\mathrm{NaCl}$ solutions were used to assess the influence of ionic strength, which was considerable for $\mathrm{pH}$ under 7. The adsorption of $\mathrm{Cr}$ (III) was also increased by increasing temperature (Fig. 2), suggesting that is an endothermic process and agreeing with other studies on different bentonites ([63]). It was also observed that the bentonite amount was also an important influencing factor, since its increase produced as well an increase in the removal of $\mathrm{Cr}(\mathrm{III})$.

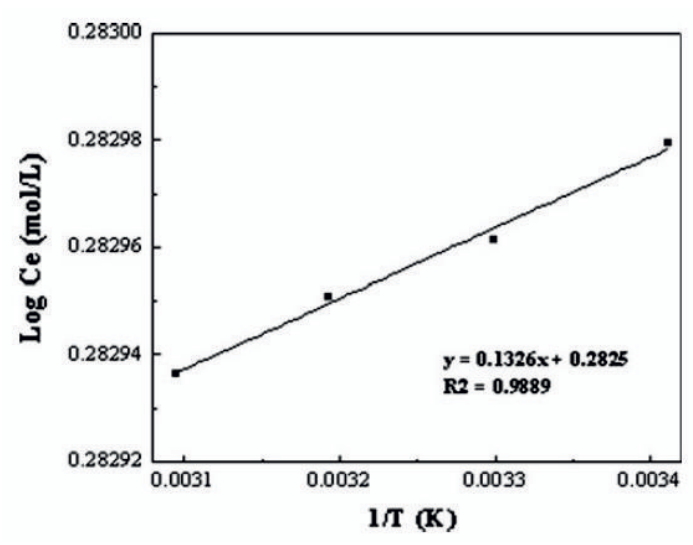

Figure 2. Effect of temperature on the adsorption of $\mathrm{Cr}(\mathrm{III})$ onto GMZ bentonite ([54]).

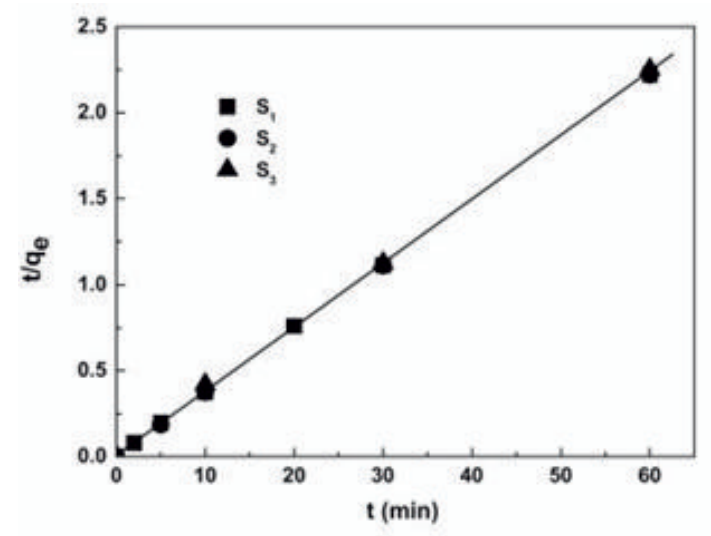

Figure 3. Absorption isotherms ([55])

Adsorption of $\mathrm{Eu}(\mathrm{III})$ on di(2-thylhexly) phosphoric acidimmobilized magnetic GMZ bentonite was also studied under the influences of temperature, $\mathrm{pH}$, contact time and concentration of metal ion ([55]). In this case, adsorption could also be described by the Langmuir isotherm and fitted the pseudo-second-order model described by equation (1). Fig. 3 shows the adsorption isotherms of $\mathrm{Eu}(\mathrm{III})$ on the modified bentonite.

The adsorption capacity was relatively low at high $\mathrm{pH}$ values, possibly explained by the competitive adsorption between $\mathrm{Eu}(\mathrm{III})$ and $\mathrm{H}^{+}$. With an increase in iron oxide particles, the adsorption capacity was decreased. Otherwise, increasing temperature induced an increase in the mobility of $\mathrm{Eu}(\mathrm{III})$ ions, which permitted the adsorption to be increased. The thermodynamic parameters indicated that the process was exothermic and spontaneous.

Efforts also have been made to improve the radionuclide adsorption capacity by using modified magnetic GMZ bentonite instead of the unmodified one ([64]). $\mathrm{La}^{3+}, \mathrm{Eu}^{3+}$ and $\mathrm{Yb}^{3+}$ adsorption was evaluated and the improvement of the method was confirmed. The influence of $\mathrm{pH}$ and metal ions was as well studied, obtaining similar results to other experiments ([55]). The method was strongly 
recommended due to the easy removal of the adsorbent and its excellent efficiency.

The use of rare earth elements (REEs) as substitutes for radionuclides such as $238 \mathrm{U}, 213 \mathrm{Th}, 83 \mathrm{Sr}$ and $234 \mathrm{Ra}$ due to their similar chemical properties and ionic radius is an important issue that has also been investigated ([53]). $\mathrm{La}$ (III) was used as a nonradioactive chemical homologue for the commonly used lanthanides and actinides, and its adsorption on GMZ bentonite was studied. Influences of $\mathrm{pH}$, bentonite content, contact time and ionic strength were assessed.

The results showed that the equilibrium on the adsorption of $\mathrm{La}(\mathrm{III})$ on GMZ bentonite was quickly achieved and that the process followed the pseudo-second-order model. Equation (1) was also valid in this case.

The effectivity of the removal of La(III) from aqueous solution by the adsorption onto GMZ bentonite was demonstrated in the equilibrium batch experiment. Other experiments proved the improvement of the removal technique using 8-hydroxyquinoline to modify the bentonite ([65]).

As the adsorption was considerably fast, it was deduced that the main process involved was the chemical adsorption rather than the physical one. It also followed Langmuir isotherm. The influence of $\mathrm{pH}$ was notable, since there was a gradual increase of $\mathrm{La}(\mathrm{III})$ adsorption with a $\mathrm{pH}$ value between 2 and 8 . Then, it maintained a high level without more significant variation with increasing $\mathrm{pH}$. The maximum removal of $\mathrm{La}$ (III) was observed at $\mathrm{pH} 8$ and reached the 96\%. Surface complexation was the main process for the control of adsorption in this case due to this strong dependence on $\mathrm{pH}([53])$.

Increasing bentonite content also induced an increase in the adsorption of $\mathrm{La}(\mathrm{III})$. It was influenced by ionic strength as well, since an increase in the concentration of $\mathrm{KCl}$ produced a reduction in the removal of $\mathrm{La}(\mathrm{III})$, probably as a result of competitive adsorption between $\mathrm{K}^{+}$and $\mathrm{La}(\mathrm{III})$. The results also showed an exchange between $\mathrm{La}^{3+}$ and $\mathrm{Na}^{+}, \mathrm{K}^{+}, \mathrm{Ca}^{2+}$ and $\mathrm{Mg}^{2+}$.

\section{Chemical effects on hydraulic properties}

\subsection{Influences of alkaline solutions}

The groundwater of Beishan area may eventually reach high $\mathrm{pH}$ values as a result of the degradation of concrete in the HLW repository. Studies have conducted on GMZ bentonite using alkaline solutions (such as $\mathrm{NaOH}$ ) in $\mathrm{pHs}$ and temperatures ([39]). The mineralogy of GMZ bentonite specimens was checked before and after the tests by X-ray diffraction (XDR) explorations.

The saturated hydraulic conductivity was obtained by means of Darcy's law. At different temperatures, the measured hydraulic conductivity experimented an increase with increasing $\mathrm{pH}$ of $\mathrm{NaOH}$ solutions (Fig. 4). The test results also revealed that, at a given $\mathrm{pH}$, there was a significant increase in the saturated hydraulic conductivity with increasing temperature and its rate also depends on temperature.

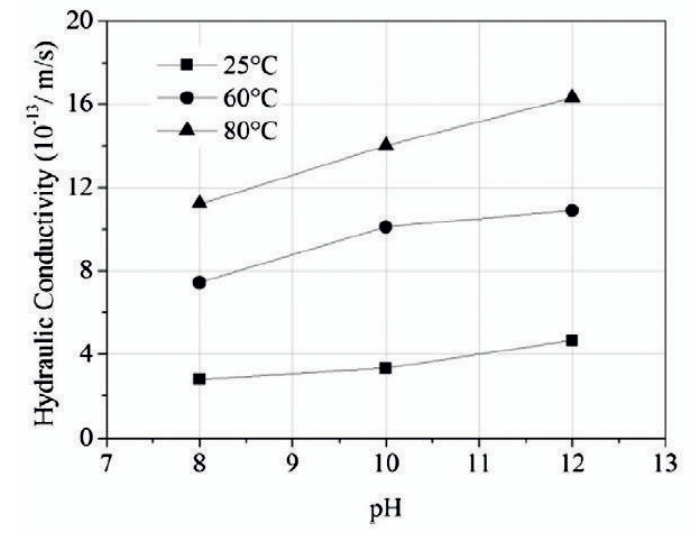

Figure 4. Relationships between the hydraulic conductivity and $\mathrm{pH}$ value of $\mathrm{NaOH}$ solutions at different temperatures ([39]).

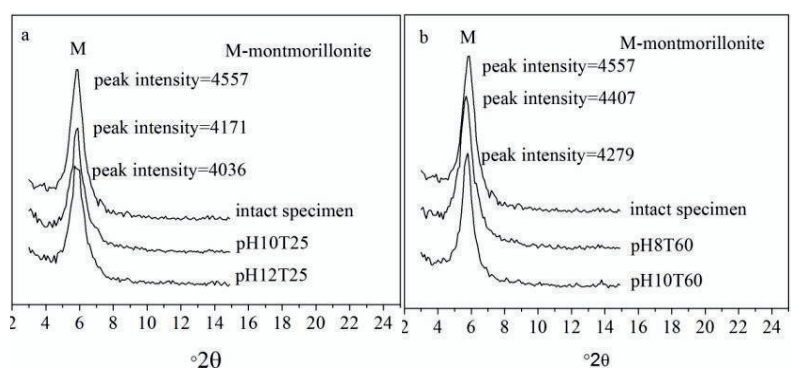

Figure 5. X-ray diffraction profiles of compacted GMZ01 bentonite specimens ([39]).

XRD results showed a decrease of montmorillonite content in GMZ bentonite after the infiltration of $\mathrm{NaOH}$ solution as a result of its dissolution (Fig. 5). Increasing $\mathrm{pH}$ induced an increase in the amount of montmorillonite dissolved, in a rate controlled by temperature. The increase in the hydraulic conductivity was explained by the decrease of the dry density of compacted bentonite as a result of the dissolution of montmorillonite. The reason for the effect of temperature on hydraulic conductivity could be the increase of effective cross section area of the pore space and the evolution of the viscosity of the injected alkaline solution.

\subsection{Influences of saline solutions}

Literatures show that influence of interactions between bentonite and pore fluid could be drastic to the performance of the bentonite barrier for groundwater with higher salinities ([66]). Beishan area groundwater mainly contains two predominant ions: $\mathrm{Na}^{+}$and $\mathrm{Ca}^{2+}$ ([40]). Therefore, studies have also been conducted on the behavior of GMZ bentonite against saline solutions. Different concentrations of $\mathrm{NaCl}$ solutions were used in some laboratory tests to assess its influences in the hydraulic conductivity of GMZ bentonite ([43]). For a void ratio lower than 0.55 , salinity had no significant influence on the saturated hydraulic conductivity. Otherwise, it increased with salinity for higher void ratio values. It was deduced that, at large pressures, bentonite tended to acquire similar fabric and structure. Therefore, the increase on the hydraulic conductivity as a consequence of increasing saline solution could be prevented with high values of confining stresses. 
The increase in the hydraulic conductivity was explained by the reduction of the bentonite swelling capacity caused by the $\mathrm{NaCl}$ solutions and by the diffuse double layer (DDL) theory. The increase in saline concentration induce a decrease in the thickness of the diffuse layer $([67,34])$, which results in the increase of the effective porosity of GMZ bentonite ([43]).

It was also discovered by other tests that the increase on the infiltrating solutions concentration induced an increase on the saturated hydraulic conductivity of bentonite as well ([68]). The results showed that $\mathrm{Na}^{+}$had more influence on the hydraulic conductivity than that of $\mathrm{Ca}^{2+}$ (Fig. 6), due to the less clogging of macro-pores induced by the $\mathrm{NaCl}$ solution compared to the $\mathrm{CaCl} 2$ one ([69,31]).

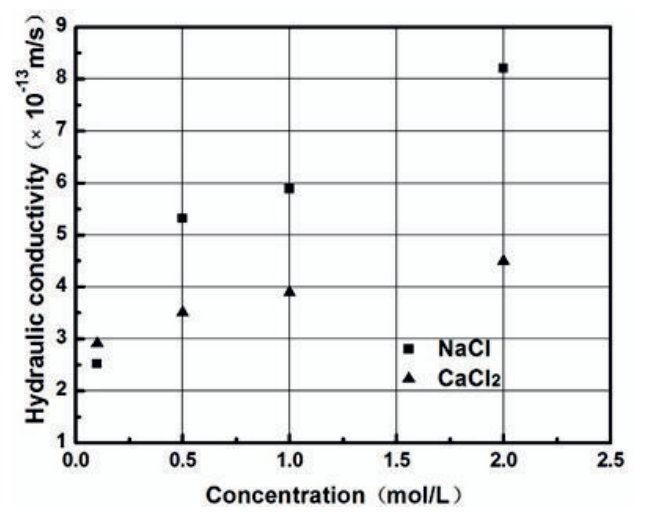

Figure 6. Comparison between the effects of the ion type on the hydraulic conductivity of GMZ bentonite ([68]).

\section{Chemical effects on mechanical properties}

\subsection{Swelling pressure}

\subsubsection{Influences of alkaline solutions}

Some studies investigated the influences of alkaline solutions on the swelling pressure of GMZ bentonite. A series of tests using $\mathrm{NaOH}$ solutions at different $\mathrm{pHs}$ and temperatures were conducted ([39]). At the beginning of the infiltration, the swelling pressure rapidly increased until reaching a peak, and then a decline was noticed before the full saturation of the specimen. After reaching the complete saturation at constant volume, the swelling pressure increased until reaching a constant value, defined as the equilibrium swelling pressure. The shape of the swelling pressure evolution curve was characterized by these two peaks (Fig. 7) and was in accordance with results achieved in similar studies using GMZ bentonite ([70,68]) and FEBEX bentonite ([71]).

Nonetheless, $\mathrm{pH}$ and temperature were observed to affect this "double-peak" shape. Increasing $\mathrm{pH}$ and temperature slightly eased off this shape. At a given temperature, increasing $\mathrm{pH}$ of $\mathrm{NaOH}$ solution induced a decrease in the swelling pressure, and its rate was controlled basically by $\mathrm{pH}$ for high temperatures. Similar results were found in different studies using Azraq Green clay ([72]) and MX-80 bentonite ([73]). Also, as in some other studies ([74]), it was noticed that the increase in temperature for a constant $\mathrm{pH}$ value caused a decrease in the swelling pressure as well (also appreciable in Fig. 7).

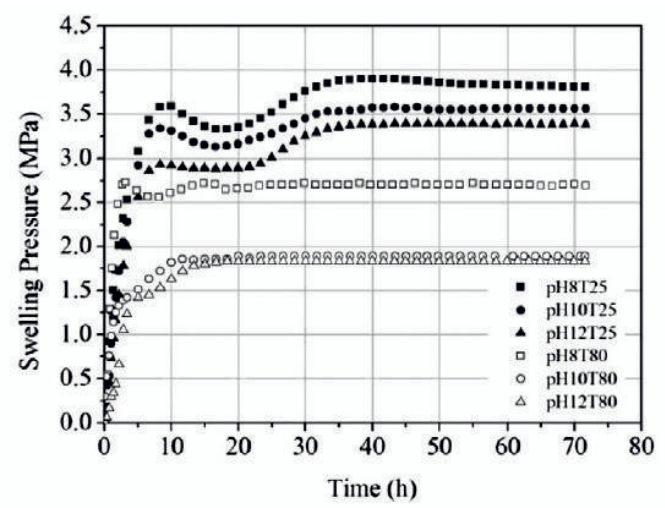

Figure 7. Swelling pressure evolution curves of GMZ bentonite ([39]).

The relationship between the montmorillonite content of GMZ bentonite and its swelling properties is very important and was the answer to some results in the tests. The decreasing of the swelling pressure due to the increase of the $\mathrm{pH}$ of $\mathrm{NaOH}$ solution was attributed to the dissolution of montmorillonite, which is the main responsible for the swelling behavior of GMZ bentonite ([39]).

\subsubsection{Influences of saline solutions}

Some studies also used salts to evaluate its effects on the swelling pressure of GMZ bentonite. De-ionized water and different concentrations of $\mathrm{NaCl}$ and $\mathrm{CaCl}_{2}$ solutions were tested on compacted GMZ bentonite ([68]).

Results revealed that salinity had a considerable influence in the swelling properties of bentonite. Increasing solutions concentration induced a decrease in the swelling pressure. There was a difference in the effect between both solutions, resulting in a bigger impact on the swelling pressure induced by the $\mathrm{CaCl}_{2}$ one (Fig. 8). It was also observed that the swelling pressure reached stability faster as the concentration of infiltrating solutions was higher.

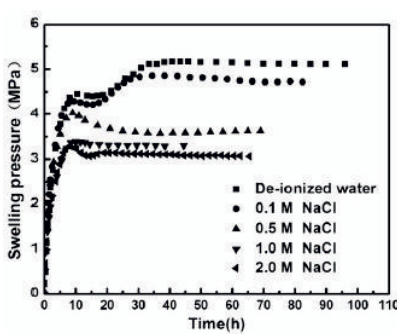

(a)

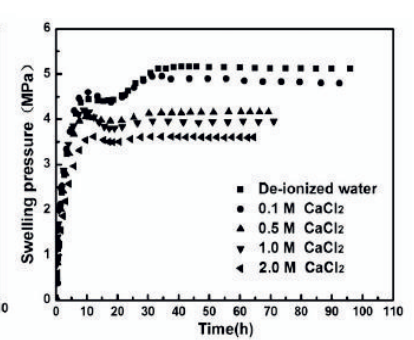

(b)
Figure 8. Influence of the concentration of (a) $\mathrm{NaCl}$ solutions and (b) $\mathrm{CaCl} 2$ solutions on the swelling pressure of $\mathrm{GMZ}$ bentonite ([68]).

It is generally accepted that there are two mechanisms of swelling of bentonite when it is exposed to water solutions: the crystalline swelling and the diffuse doublelayer swelling ([75-76]). In Fig. 9, the stage I corresponds to crystalline swelling (first peak in Fig. 8), followed by a 
collapse of the soil skeleton induced by swelling of aggregates (between stage I and II). Stage III represents the second peak of Fig. 8 caused by the diffuse doublelayer repulsion, which becomes the governing swelling mechanism. The DDL theory is used to explain the reduction of the swelling pressure with increasing salt concentration, since it causes a decrease in the DDL thickness and, hence, a reduction in the repulsive forces between clay particles $([67,34])$.

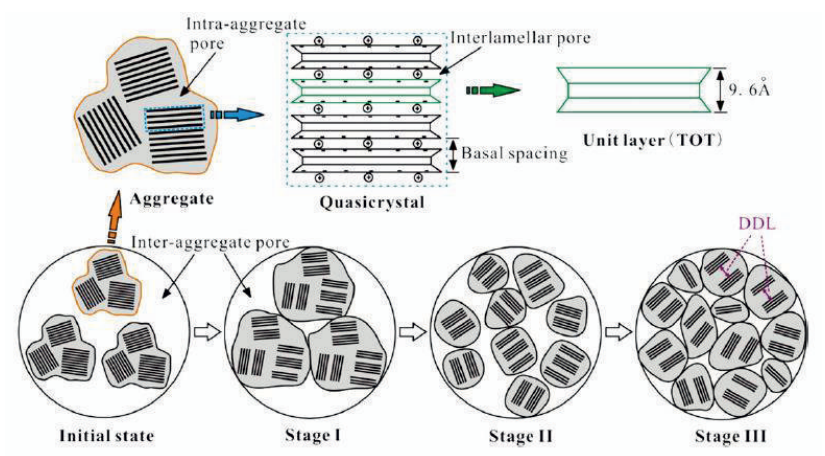

Figure 9. Conceptual diagrams of constant-volume swelling process and microstructure of compacted GMZ bentonite $([68,77-78])$.

Some other studies also evaluated the influence of saline solutions on the swelling behavior of GMZ bentonite. Different concentrations of $\mathrm{NaCl}$ and $\mathrm{Na}_{2} \mathrm{SO}_{4}$ solutions were used on both GMZ Na- and Ca-bentonites for a series of constant-volume tests in which the dry density of bentonite was also varied ([79]).

The results showed differences between the behaviors of $\mathrm{Na}-$ and $\mathrm{Ca}$-bentonite. The swelling pressure of $\mathrm{Na}$ bentonite had a linear decrease with increasing saline solutions. In the case of Ca-bentonite, the swelling pressure first increased linearly with the concentration of solutions until a certain value, when the swelling pressure had a linear decrease.

\subsection{Volume changes}

The influence of saline solutions on the volume change behavior of GMZ bentonite was also investigated. Some swelling tests under different vertical loads were conducted using $\mathrm{NaCl}$ solutions to evaluate its effect on the swelling strain and compressibility of GMZ bentonite ([43]).

The results revealed that swelling strain of bentonite was increased by increasing concentration of saline solutions. This process was dominated by the dissipation of matric suction and the increase of diffuse ion layer repulsion ([43]). The compression index $\left(\mathrm{C}_{\mathrm{c}}{ }^{*}\right)$ is a parameter which describes how the void ratio varies as a function of the effective stress. It was observed to increase first and then turned to decrease while the void ratio decreased or the vertical stress increased for different concentrations of $\mathrm{NaCl}$ solution. If the concentration was increased, then $\mathrm{C}_{\mathrm{c}}{ }^{*}$ experimented a decrease. The secondary consolidation coefficient $\left(\mathrm{C}_{a}\right)$, which refers to the part of the compression that is recorded after pore water pressure cease to change, increased linearly with $\mathrm{C}_{\mathrm{c}}{ }^{*}$. A bi-linear relationship between $\mathrm{C}_{a}$ and the swelling index $\left(\mathrm{C}_{\mathrm{s}}^{*}\right)$ was established during unloading.
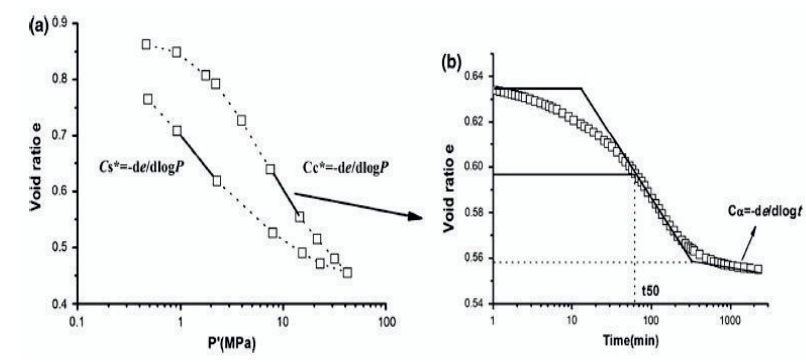

Figure 10. Determination of the parameters $\mathrm{C}_{\mathrm{c}}{ }^{*}, \mathrm{C}_{\mathrm{s}}{ }^{*}$ and $\mathrm{C}_{\alpha}$ ([43]).

The influence of cations on the swelling strain of GMZ bentonite was studied as well in a series of tests using different concentrations of $\mathrm{NaCl}$ and $\mathrm{CaCl}_{2}$ solutions ([44]). Results revealed that the swelling strain decreased in a form of power function with increasing concentration of saline solutions. At a given salt concentration, the bentonite specimen tested with $\mathrm{NaCl}$ solutions had a higher swelling strain than that tested with the $\mathrm{CaCl}_{2}$ ones.

During the injection of the saline solutions, it was noticed that the primary swell coefficient of bentonite decreased with increasing concentration of the solutions, and the secondary swell in contrast was more slowly. Inhibition of salt solution on the swelling strain of bentonite mainly happened during the secondary swell. DDL theory also explains this phenomena, since the diffusion layer thickness is notably reduced due to the increasing salt concentration, resulting in a reduction of the repulsion between the clay particles $([67,34])$ and, hence, a reduction in swelling strain $([80-81,31])$. The difference between the influence of $\mathrm{Na}^{+}$and $\mathrm{Ca}^{2+}$ were explained by the larger basal space of Na-bentonite than that of $\mathrm{Ca}$ bentonite. With $\mathrm{CaCl}_{2}$ infiltrations, some $\mathrm{Na}^{+}$is replaced by $\mathrm{Ca}^{2+}$ transforming part of the bentonite into $\mathrm{Ca}$ bentonite ([82]), which has less basal space than $\mathrm{Na}$ bentonite and, consequently, less extensive swelling ([44]).

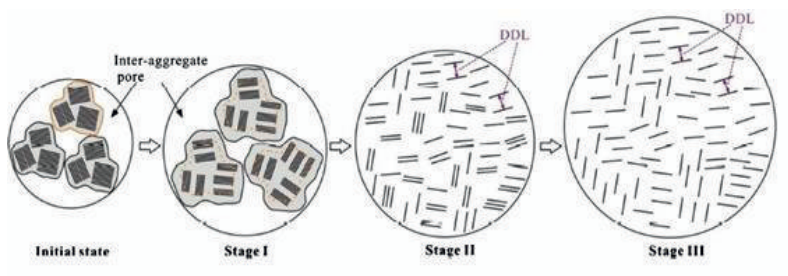

Figure 11. Conceptual diagram of micro-structural swelling process of compacted GMZ01 bentonite ([44,77-78]).

After swelling tests under constant load, when GMZ bentonite specimens were totally saturated with saline solutions and stable, compression tests were conducted applying the conventional step loading method ([43]). It was found that there was an almost linear relationship between the odometer modulus (Eodo) and the vertical effective stress ( $\left.\mathrm{P}^{\prime}\right)$. As the vertical pressure increased or the void ratio decreased upon loading, the consolidation coefficient $\left(\mathrm{C}_{\mathrm{v}}\right)$ was observed to first decrease and then 
turn to increase. $\mathrm{C}_{\mathrm{v}}$ incremented with the increase of $\mathrm{NaCl}$ concentration, regardless the specimen was under loading or unloading.

Another important issue is the cyclically change of the chemistry of the groundwater during a long-term operation of a repository as a result of the fluctuations and temperature among other factors. To study how this cycles can influence the swelling behavior of GMZ bentonite, some studies have been conducted using different concentrations of $\mathrm{CaCl}_{2}$ solutions on a series of one-dimensional free swelling tests with cyclic infiltrations of this saline solutions ([45]).

The results revealed that the total swelling strains of bentonite had an increase with increasing concentration of the solutions. It happened after more than one cycle of salinization-desalinization, since in the first salinization process the trend of the swelling strain was inversed. At a given concentration of salt solution, and especially for the highest ones, the total vertical displacement on bentonite happened basically during the first salinizationdesalinization cycle. The total swelling strains measured over the first salinization decreased as the concentration of salts increased, which means that the concentration of $\mathrm{CaCl}_{2}$ had a notable restricting effect on the swelling behavior of bentonite ([45]).

In the first desalinization, the relative swelling strain increased abruptly with an increase in the concentration of the saline solutions. In contrast to the tests with low concentrations of salt solutions, in those for high concentrations obvious relative swelling strains were noticed over desalinization and contraction strains were observed over salinization processes. It was also noticed that as the number of salinization-desalinization cycles increased, the swelling strain of the specimens was incremented as well (Fig. 12). When exposed to salinization-desalinization cycle, the swelling strain and its associated contraction strain were almost reversible from the third salinization process.
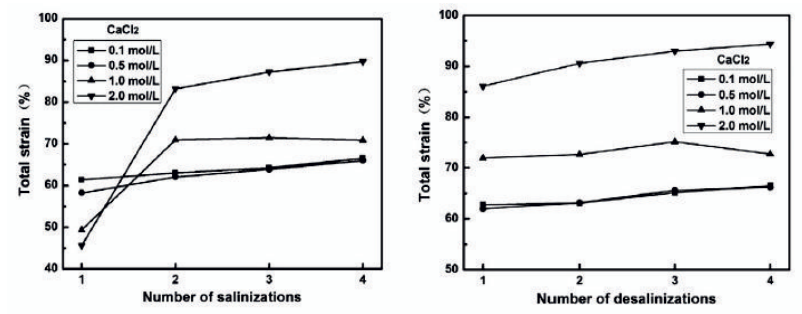

Figure 12. Effect of the number of salinizations and desalinizations on the total strain of GMZ bentonite ([45]).

\section{Conclusions}

The sorption of $\mathrm{Ni}(\mathrm{II})$ on GMZ bentonite is endothermic and spontaneous. It increases with an increase in $\mathrm{pH}$ values lower than 8.5 , and then maintain a high level at values above 8.5 . It is also dependent on foreign cations at a low $\mathrm{pH}$, and independent at high $\mathrm{pH}$ values. The presence of humic acid enhances the sorption at low $\mathrm{pH}$ values, and reduces it at high $\mathrm{pH}$ values.

Removal of $\mathrm{Cr}$ (III) by means of adsorption onto GMZ bentonite is increased with increasing $\mathrm{pH}$ until a value of 7. Temperature and bentonite concentration also enhance the adsorption process, which is strongly dependent on ionic strength as well. Adsorption of $\mathrm{Eu}(\mathrm{III})$ can be improved using di(2-thylhexly) phosphoric acidimmobilized magnetic GMZ bentonite. For high $\mathrm{pH}$ values, the adsorption is low and it can be increased by increasing temperature. The adsorption of $\mathrm{La}$ (III) gradually increases with $\mathrm{pH}$ between 2 and 8 . The adsorption process is probably dominated by surface complexation. It is also increased with an increment of bentonite content and decreases with increasing $\mathrm{KCl}$ concentration.

The hydraulic conductivity of GMZ bentonite increases with the $\mathrm{pH}$ of $\mathrm{NaOH}$ solutions at a rate which depends on the temperature. The infiltration of $\mathrm{NaOH}$ solution in GMZ bentonite produces a "double peak" structure in the swelling pressure evolution curve, in which the swelling pressure first increase rapidly until reaching a peak, and then, there is an intermediate phase with a decline until reaching another peak at full saturation and constant volume. The increase of $\mathrm{pH}$ and temperature induces a decrease in swelling pressure. For a given temperature, $\mathrm{NaOH}$ presence in $\mathrm{GMZ}$ bentonite induces a decrease of montmorillonite content. The increase of $\mathrm{pH}$ and/or temperature also produces a decrease of montmorillonite. The swelling pressure is observed to decrease with decreasing montmorillonite content.

The increase of $\mathrm{NaCl}$ and $\mathrm{CaCl}_{2}$ saline solutions also increase the hydraulic conductivity of bentonite. For high concentrations of solution, the hydraulic conductivity is more influenced by the presence of the Na-based salt.

An increase of the concentration of $\mathrm{NaCl}$ and $\mathrm{CaCl}_{2}$ solutions also produce a decrease in the swelling pressure, which is higher with the $\mathrm{CaCl}_{2}$ one. Stability is faster reached as much high is the concentration of salt solutions. Swelling strain of GMZ bentonite decrease as the concentration of $\mathrm{NaCl}$ solution increases. For given concentrations, the swelling strain of the bentonite with infiltrations of $\mathrm{NaCl}$ solutions is higher than that with $\mathrm{CaCl}_{2}$. An increase of the concentration of the solutions induce a decrease on the compression index $\mathrm{C}_{\mathrm{c}}{ }^{*}$ and an increase on the consolidation coefficient $\mathrm{C}_{\mathrm{v}}$.

There are differences in the influence of saline solutions on the swelling behavior between $\mathrm{Na}$-bentonite and $\mathrm{Ca}$ bentonite.

The increasing number of salinization-desalinization cycles induce an increase in the volume change of GMZ bentonite with $\mathrm{CaCl}_{2}$ solutions.

Considering the complexity of the operation conditions and long run of the repository, further investigation is needed to totally understand the influences of coupling factors and time on chemical behavior of the material in the HLW repository.

\section{Acknowledgements}

The author would like to thank his colleagues and students: Isaac Moya-Carreras, Yong-Gui Chen, Bao Chen and Yu-Jun Cui, Chun-Ming Zhu, Feng Zhang and Yong He etc. for their contributions to this work.

The author is also grateful to China Atomic Energy Authority (Project [2011]1051) and the National Natural 
Science Foundation of China (Projects No. 41527801, 40802069,41030748 ) for the financial supports.

\section{References}

1. Pusch, R. 1983. KBS report 83-46.

2. Chapman, N.A., McKinley, I.G. 1989. John Wiley \& Sons.

3. Romero, E., Gens, A., Lloret, A., 1999. Engineering Geology. 54,117-127

4. Ye, W.M., Cui, Y.J., Qian, L.X., Chen, B. 2009. Engineering Geology 108, 169-176.

5. Ye, W.M., Chen, Y.G., Chen, B., Wang, Q., Wang, J. 2010. Engineering Geology 116, 12-20.

6. Zhang, H.Y., Cui, S.L., Zhang, M., Jia, L.Y. 2012. Nuclear Engineering and Design 242, 115-123.

7. Li, X.L., Bastiaens, P., Van Marcke P., Verstricht, J., Chen, G.J., Weetjens, E., Sillen, X. 2010. Journal of Rock Mechanics and Geotechnical Engineering 2(2), 103-110.

8. Tripathy S., Thomas H. R. and Bag R., 2015. Journal of Hazardous, Toxic, and Radioactive Waste. 10.1061/(ASCE)HZ.2153-5515.0000272.

9. Lloret, A., Villar, M.V. 2007. Physysics and Chemistry of the Earth 32, 701-715.

10. Dixon, D.A. 2000. POSIVA Report 2000-04. Posiva Oy, Helsinki, Finland.

11. Hurel, C., Marmier, N. 2010. Journal of Radioanalytical Nuclear Chemistry 284, 225-230.

12. Nakashima, Y. 2006. Clay Minerals 41, 659-668.

13. Herbert, H.-J., Moog, H.C. 1999. Engineering Geology 54, 55-65.

14. Imbert, C., Villar, M.V. 2006. Applied Clay Science 32, 197-209.

15. Tang, A.M., Cui, Y.J., Le, T.T. 2008. Applied Clay Science 41, 181-189.

16. Kanno, T., Fujita, T., Takeuchi, S., Ishikawa, H., Hara, K., Nakano, M. 1999. International Journal for Numerical and Analytical Methods in Geomechanics 23, 1281-1307.

17. Nguyen, T.S., Selvadurai, A.P.S., Armand, G. 2005. International Journal of Rock Mechanics and Mining Sciences 42, 639-651.

18. Gens, A., Olivella, S. 2006. Chinese Journal of Rock Mechanics and Engineering 25, 670-680.

19. Gens, A., Sánchez, M., Guimarães, L.D.N., Alonso, E.E., Lloret, A., Olivella, S., Villar, M.V., Huertas, F. 2009. Geotechnique 59, 377-399.

20. Olivella, S., Carrera, J., Gens, A., Alonso, E.E. 1994. Transport in Porous Media 15, 271-293.

21. Gawin, D., Baggio, P., Schrefler, B.A. 1995. International Journal for Numerical Methods in Fluids 20, 969-987.

22. Thomas, H.R., He, Y. 1995. Geotechnique 45, 677689.

23. Liu, X.Y., Zhang, C.Y., Liu, Q.S. 2008. Advanced Materials Research 33-37, 639-644.

24. Åkesson, M., Jacinto, A.C., Gatabin, C., Sanchez, M., Ledesma, A. 2009. Geotechnique 59, 307-318.

25. Chen, Y.F., Zhou, C.B., Jing, L.R. 2009. Computers and Geotechnics 36, 1308-1329.
26. Fernández, R., Cuevas, J., Sánchez, L. 2006. Applied Geochemistry 21(6), 977-992.

27. Tripathy, S., Sridharan, A., Schanz, T., 2004. Can. Geotech. J. 41, 437-450.

28. Rao M, Shivananda P. 2005. Can Geotech J 42:307315

29. Sánchez, L., Cuevas, J., Ramírez, S., de León, D.R., Fernández, R., de la Villa, R. V., Leguey, S. 2006. Applied Clay Science 33(2), 125-141.

30. Rao, S.M., Thyagaraj, T., Thomas, H.R., 2006. Geotechnique 56 (10), 707-713

31. Castellanos, E., Villar, M.V., Romero, E., Lloret, A., Gens, A. 2008. Physics and Chemistry of the Earth 33, S516-S526.

32. Siddiqua, S., Blatz, J., Siemens, G., 2011. Can. Geotech. J. 48, 199-213

33. Barbour, S.L., Fredlund, D.G. 1989. Canadian Geotechnical Journal 26, 551-562

34. Mitchell, J.K. 1993. John Wiley and sons, New York.

35. Barbour, S.L., Yang N. 1993. Can Geotech J 30:920-934

36. Ye, W.M., Borrell, N.C., Zhu, J.Y., Chen, B., Chen, Y.G. 2014a. Engineering Geology 169, 41-49.

37. CAEA (China Atomic Energy Authority) 2006. Ministry of environment protection \& ministry of science and technology (in Chinese).

38. Wang, J., Chen, W.M., Su, R., Guo, Y.H., Jin., Y.X. 2006. Chinese Journal of Rock Mechanics and Engineering 25, 801-812 (in Chinese).

39. Ye, W.M., Zheng, Z.J., Chen, B., Chen, Y.G., Cui, Y.J., Wang, J. 2014b. Applied Clay Science 101, 192-198.

40. Guo, Y.H., Yang, T.X., Liu, F.S. 2001. Uranium Geology 17 (3), 184-189.

41. Liu, Y.M., Wen, Z.J. 2003. Mineral Rocks 23, 42-45 (in Chinese).

42. Wen, Z.J. 2005. Acta Petrologica et Mineralogica 24, 583-586 (in Chinese).

43. Ye, W.M., Zhang, F., Chen, B., Chen, Y.G., Wang, Q., Cui, Y.J. 2014c. Environmental Earth Sciences 72, 2621-2630.

44. Ye, W.M., Zhu, C.M., Chen, Y.G., Chen, B., Cui, Y.J., Wang, J. 2015. Environmental Earth Sciences 74, 793-802.

45. Zhu, C.M., Ye, W.M., Chen, Y.G., Chen, B., Cui, Y.J. 2015. Engineering Geology 184, 104-110.

46. Wang, J., Liu, Y.M., Zhao, X.G. 2011. BRIUG PEBS Internal Deliverable DB-2.1.

47. Madsen, F.T. 1998. Clay Minerals 33, 109-129.

48. Montes, H.G., Duplay, J., Martinez, L., Geraud, Y., Rousset-Tournier, B. 2003. Applied Clay Science 23, 309-321.

49. Nakashima, Y. 2004. Journal of Nuclear Science and Technology 41, 981-992.

50. Li, J.X., Hu, J., Sheng, G.D., Zhao, G.X., Huang, Q. 2009. Colloids and Surfaces A: Physicochemical and Engineering Aspects 349, 195-201.

51. Wang, S.W., Dong, Y.H., He, M.L., Chen, L., Yu, X.J. 2009a. Applied Clay Science 43, 164-171.

52. Wang, S.W., Hu, J., Li, J.X., Dong, Y.H. 2009 b. Journal of Hazardous Materials 167, 44-51. 
53. Chen, Y.G., Zhu, C.M., Sun, Y.H., Duan, H.Y., Ye, W.M., Wu, D.B. 2012a. Journal of Radioanalytical Nuclear Chemistry 292, 1339-1347.

54. Chen, Y.G., He, Y., Ye, W.M., Lin, C.H., Zhang, X.F., Ye. B. 2012b. Environmental Earth Sciences 67, 1261-1268.

55. Chen, Y.G., Zhu, B.H., Wu, D.B., Wang, Q.G., Yang, Y.H., Ye, W.M, Guo, J.F. 2012c. Chemical Engineering Journal 181-182, 387-396.

56. Chen, Y.G., He, Y., Ye, W.M., Sui, W.H., Xiao, M.M. 2013. Transactions of Nonferrous Metals Society of China 23, 3482-3489.

57. Chen, Y.G., He, Y., Ye, W.M., Jia, L.Y. 2015. Journal of Industrial and Engineering Chemistry 26, 335-339.

58. Yang, S.T., Li, J.X., Lu, Y., Chen, Y.X., Wang, X.K. 2009. Applied Radiation and Isotopes 67, 16001608.

59. Pan, D.Q., Fan, Q.H., Li, P., Liu, P.L., Wu, W.S 2011. Chemical Engineering Journal 172, 898-905.

60. Zhao, D.L., Chen, S.H., Yang, S.B., Yang, X., Yang, S.T. 2011. Chemical Engineering Journal 166, 1010-1016.

61. Wu, T., Wang, H., Zheng, Q., Zhao, Y.L., Van Loon, L.R. 2014. Applied Clay Science 101, 136-140.

62. Ho, Y.S., McKay, G. 1998. Process Safety and Environmental Protection 76, 183-191.

63. Tahir S.S., Naseem R. 2007. Separation and Purification Technology 53, 312-321.

64. Wu, D.B., Zhu, C.M., Chen, Y.G., Zhu, B.H., Yang, Y.H., Wang, Q.G., Ye, W.M. 2012. Applied Clay Science 62-63, 87-93.

65. Chen, Y.G., Huang, R.Q., Zhu, C.M., Wu, D.B., Sun, Y.H., He, Y., Ye, W.M. 2014. Journal of Radioanalytical Nuclear Chemistry 299, 665-674.

66. Rao, S.M., Thyagaraj, T., 2007. Appl. Clay Sci. 38 (1), 113-129
67. Yong, R.N., Warkentin, B.P. 1975. Elsevier, Amsterdam.

68. Zhu, C.M., Ye, W.M., Chen, Y.G., Chen, B., Cui, Y.J. 2013. Engineering Geology 166, 74-80.

69. Pusch, R. 2001. SKB Technical Report TR-01-07, Stockholm.

70. Ye, W.M., Wan, M., Chen, B., Chen, Y.G., Cui, Y.J., Wang, J. 2013. Environment Earth Science 68(1), 281-288.

71. Villar, M.V., Lloret, A. 2008. Applied Clay Science 39, 38-49.

72. Abdullah, W.S., Alshibli, K.A., Al-Zou'bi, M.S. 1999. Applied Clay Science 15, 447-462.

73. Herbert, H.-J., Kasbohm, J., Sprenger, H., Fernández, A.M., Christian, R. 2008. Physics and Chemistry of the Earth 33(supplement1), S327S342.

74. Lingnau, B.E., Graham, J., Yarechewski, D., Tanaka, N., Gray, M.N. 1996. Engineering Geology 41(1-4), 103-115.

75. Madsen, F.T., Müller-VonMoos, M. 1989. Applied Clay Science 4, 143-156.

76. Savage, D. 2005. SKI Report 54.

77. Villar, M.V. 2002. Publicación Técnica ENRESA 01/2002, Madrid (44 pp).

78. Suzuki, S., Prayongphan, S., Ichikawa, Y., Chae, B. 2005. Applied Clay Science 29, 89-98.

79. Sun, D.A., Zhang, L., Li, J., Zhang, B.C. 2015. Applied Clay Science 105-106, 207-216.

80. Karnland, O. 1997. SKB technical report 97-31. Swedish Nuclear Fuel and Waste Management Co, Stockholm.

81. Mata, C. 2003. Ph.D. Thesis. Universitat Politecnica de Catalunya, Barcelona.

82. Montes, H.G., Geraud, Y. 2004. Colloids and Surfaces A: Physicochemical and Engineering Aspects 235, 17-23. 